\title{
The Regulation of Stable RNA Synthesis in the Blue-green Alga Anacystis nidulans: Effect of Leucine Deprivation and 5-Methyltryptophan Inhibition
}

\author{
BY R. JOHN SMITH \\ Department of Biological Sciences, University of Lancaster, Bailrigg, \\ Lancaster, $L A$ I $4 Y Q$ \\ AND NOEL G. CARR \\ Department of Biochemistry, University of Liverpool, \\ P.O. Box I47, Liverpool, L69 3BX \\ (Received I8 February I977; revised 4 July 1977)
}

The expression of phenomena associated with the bacterial function controlling RNA synthesis was studied in leucine-deprived or 5-methyltryptophan-treated cultures of Anacystis nidulans. Both procedures retarded cell growth, RNA and protein accumulation, elicited the accumulation of high intracellular concentrations of guanosine 5'-diphosphate- $3^{\prime}$ diphosphate (ppGpp) and guanosine 5'-triphosphate-3'-diphosphate (pppGpp), and promoted a regime of non-coordinate synthesis of stable and messenger RNA. The rate of polymerization of nascent RNA chains did not appear to be retarded in the growth-limited cultures.

\section{INTRODUCTION}

The RNA composition of Anacystis nidulans is regulated according to growth rate in a manner similar to that described for bacteria. Thus increase in growth rate produces organisms with larger mass and volume and which contain more RNA per cell (Mann \& Carr, 1974). The control of RNA synthesis in A. nidulans deviates from that of heterotrophic prokaryotes in that the ratio of transfer RNA to ribosomal RNA does not alter with variation in growth rate (Mann \& Carr, 1973). The proportions of the genome coding for the major RNA fractions and the relative rates of expression of stable and unstable RNA cistrons are comparable to those of Escherichia coli (Smith \& Carr, 1977) and encourage the further comparison of the regulation of RNA synthesis in autotrophic and heterotrophic prokaryotes. The accumulation of the stable RNA species (rRNA and tRNA) in certain bacteria is under the control of a regulatory mechanism known as the $\mathrm{RC}$ function which is controlled indirectly by the intracellular supply of amino acids and restrictions placed upon the aminoacylation of tRNA (Maaløe \& Kjeldgaard, I966; Eldin \& Broda I968). When aminoacylation of the tRNA pool is limited, either by a deficiency in one or more amino acids within the intracellular pool or by inhibition of the aminoacyl-tRNA synthetases, an idling reaction is initiated in the process of polypeptide chain elongation (Cashel \& Gallant, I969; Haseltine et al., 1972). This reaction gives rise to two unusual guanosine nucleotides, guanosine 5'-diphosphate-3'-diphosphate (ppGpp) and guanosine 5'-triphosphate- $3^{\prime}$ diphosphate (pppGpp) (Cashel, I969; Cashel \& Kalbacher, 1970).

In bacteria the effects of the RC function are primarily dependent upon the state of the aminoacyl-tRNA pool and not upon that of the amino-acid pool of the cell (Kaplan, 1969). These effects may be distinguished by the use of inhibitors of aminoacyl-tRNA synthetase activity in $E$. coli which prevent aminoacylation but do not deplete the amino-acid pools. 
The tryptophan analogue 5-methyltryptophan has been used for this purpose (de Boer et al., 1973). It inhibits aminoacylation of tryptophan-specific tRNA but is not incorporated into protein (Pardee, Shore \& Prestidge, I957; Pardee \& Prestidge, 1958).

The present communication describes phenomena present in $A$. nidulans which are characteristic of the expression of the RC function in heterotrophic bacteria, and compares the elicitation of the phenomena through amino-acid deprivation of an auxotroph and by addition of an amino-acid analogue. The results suggest that the regulatory phenomena in $A$. nidulans is primarily elicited by reduced aminoacylation of tRNA.

\section{METHODS}

Organisms. These were Anacystis nidulans strain 625 (from The Culture Collection of Algae at the University of Texas, previously at the University of Indiana), and strain LeuzoI, a leucine-requiring auxotroph derived from strain 625. We are indebted to Dr W. Ford Doolittle for strain Leu201.

Media and growth conditions. Cultures were maintained in medium C (Kratz \& Myers, 1955) modified by the addition of $\mathrm{NaHCO}_{3}\left(\mathrm{I} \cdot 0 \mathrm{~g} \mathrm{l}^{-1}\right)$. Low-phosphate medium $\mathrm{C}$ was obtained by reducing the $\mathrm{KH}_{2} \mathrm{PO}_{4}$ concentration to $7.0 \times \mathrm{IO}^{-5} \mathrm{M}$ and adding Tris to $0.4 \mathrm{~g} \mathrm{l}^{-1}$; the $\mathrm{pH}$ was adjusted to 7.8 with $\mathrm{I} \mathrm{M}-\mathrm{HCl}$. The leucine-requiring auxotrophic strain was grown in modified medium $\mathrm{C}$ supplemented with leucine $(5 \times$ $\mathrm{IO}^{-3} \mathrm{M}$ ). Cultures were maintained as previously described (Smith \& Carr, 1977) or as $100 \mathrm{ml}$ cultures in $250 \mathrm{ml}$ conical flasks incubated at $35 \pm 0.5{ }^{\circ} \mathrm{C}$ in an orbital incubator at $84 \mathrm{rev}$. $\mathrm{min}^{-1}$ (L.H. Engineering, Stoke Poges, Buckinghamshire) aerated with air $/ \mathrm{CO}_{2}(95: 5, \mathrm{v} / \mathrm{v})$ and illuminated by seven fluorescent tubes (Atlas Warm White, 13 W).

Experimental cultures were derived from $\mathrm{i} 6 \mathrm{~h}$ cultures which had a mean generation time of 5 to $6 \mathrm{~h}$ and a turbidity $\left(E_{750}\right)$ of 0.25 to 0.35 . To estimate the effects of 5 -methyltryptophan, cultures were divided into two: one part received 5-methyltryptophan to a final concentration of $100 \mu \mathrm{g} \mathrm{ml}^{-1}$; the other received no subsequent additions and was maintained as a growing control. To deprive cultures of strain Leuzor of leucine, exponential phase cultures were poured into cooled $250 \mathrm{ml}$ bottles, centrifuged at $6{ }^{\circ} \mathrm{C}$ and the pellet was washed in leucine-free medium. The procedure was repeated three times. Small volumes, especially cultures containing ${ }^{32} \mathrm{P}$ ]orthophosphate were deprived of leucine by filtration on nitrocellulose filters (Sartorius membrane filter MF50, $25 \mathrm{~mm}$ diam., $0.46 \mu \mathrm{m}$ pore size) followed by washing with 6 vols of prewarmed leucine-deficient medium. The final resuspension was in prewarmed medium. Control cultures were derived from material taken through the procedures and immediately resupplied with leucine $(5 \times$ $10^{-3} \mathrm{M}$ ). The former procedure took 20 to $30 \mathrm{~min}$; the latter took about $15 \mathrm{~min}$.

Growth was measured at $750 \mathrm{~nm}$ in a Cecil spectrophotometer (Cecil Instruments, Cambridge) using a I cm light path.

Radioisotope incorporation. The incorporation of $\left[2-{ }^{14} \mathrm{C}\right]$ uracil, $\left[\mathrm{G}-{ }^{3} \mathrm{H}\right]$ tryptophan or $\left[\mathrm{I}-{ }^{14} \mathrm{C}\right]$ leucine (The Radiochemical Centre, Amersham) into acid-precipitable, and alkaline-stable acid-precipitable material was followed as described by Pigott \& Midgley (1968). Glass fibre filters (25 nm, Whatman GF/C) were used in conjunction with a Nuclear Chicago Isocap 300 scintillation counter.

Isolation of phosphorylated nucleotides in formic acid extracts. Cultures grown in low-phosphate medium $\mathrm{C}$ were supplemented with $\left.{ }^{32} \mathrm{P}\right]$ orthophosphate (specific radioactivity $5000 \mathrm{Ci}^{-1}$, final concentration $50 \mu \mathrm{Ci} \mathrm{ml}^{-1}$; The Radiochemical Centre, Amersham) for at least one generation time before use. In experiments which required the removal of leucine from strain LeuzoI cultures, $\left.{ }^{32} \mathrm{P}\right]$ orthophosphate was included in the resuspension medium at the same specific radioactivity.

Samples $(0.2 \mathrm{ml})$ were removed into ice-cold centrifuge tubes containing $0.1 \mathrm{ml}$ of $98 \%$ (Analar) formic acid. After $20 \mathrm{~min}$ the mixtures were centrifuged $\left(3000 \mathrm{~g}, 4{ }^{\circ} \mathrm{C}\right.$, $\left.10 \mathrm{~min}\right)$ and the upper portion of the supernatant was collected. Samples (Io $\mu$ l) were applied to polyethyleneimine-cellulose plastic-backed thin-layer plates (cat. no. G-I440-PEI, $20 \times 20 \mathrm{~cm}$; Schleicher and Schuell, Dassel, West Germany) and chromatographed as described by Cashel (1969) in $1.5 \mathrm{M}^{-} \mathrm{KH}_{2} \mathrm{PO}_{4} \mathrm{pH} 3 \cdot 4$. Radioactive material was located by autoradiography and these areas were cut from the plates and counted in a scintillation counter. The nucleotides ppGpp, pppGpp and GTP were identified from their $R_{F}$ values as described by Cashel (I969). The validity of the technique for isolating ppGpp has been confirmed by Mann, Carr \& Midgley (1975) by comparison with ppGpp isolated from $E$. coli and co-chromatographed with the $A$. nidulans extract in three separate systems and by two-dimensional chromatography.

$R N A$ and protein estimation. Duplicate samples $(5 \mathrm{ml})$ were treated essentially as described by Mann $e t$ al. (1975). The product of the $\mathrm{NaOH}$ digest was used to estimate RNA content by the method of Schneider (1957) and protein by the method of Lowry et al. (195I).

DNA-RNA hybridization. To determine accurately changes in the relative flux of labelled precursor into 


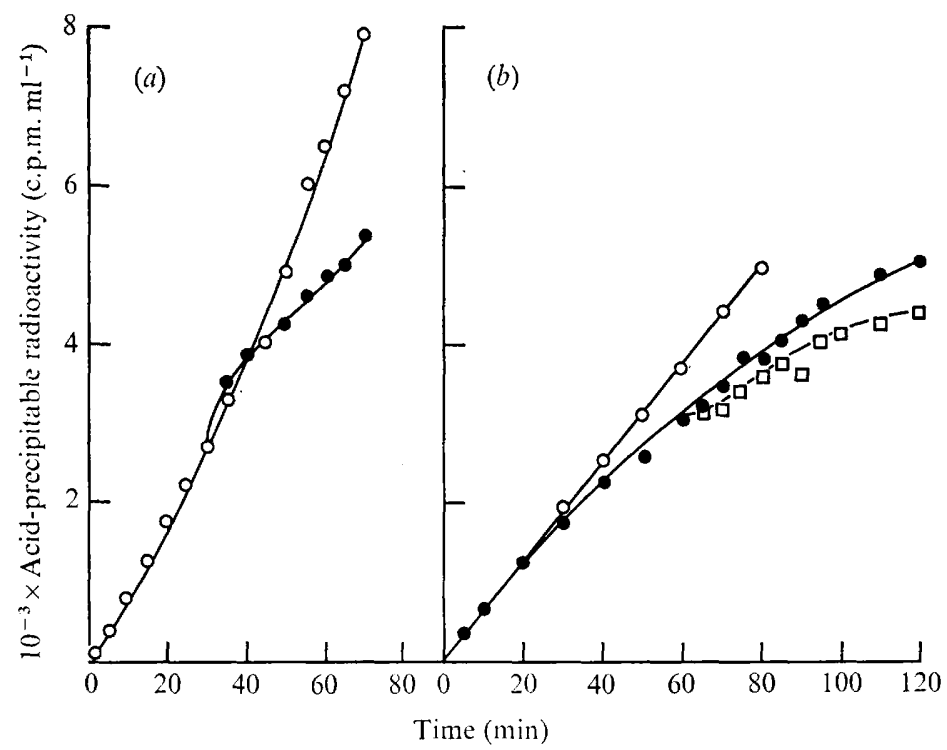

Fig. I. Effect of 5-methyltryptophan on the incorporation of amino-acid supplements into protein in $A$. nidulans. (a) Incorporation of $\mathrm{L}-\left[\mathrm{G}^{-3} \mathrm{H}\right] \operatorname{tryptophan}\left(20 \mathrm{mCi} \mathrm{mmol}{ }^{-1}, 0 \cdot 2 \mu \mathrm{Ci} \mathrm{ml}^{-1}\right)$ into acidprecipitable material: $5 \mathrm{MT}\left(100 \mu \mathrm{g} \mathrm{ml}^{-1}\right.$ ) was added at $30 \mathrm{~min}$. (b) Effect of addition of DL-tryptophan on the incorporation of $\left[\mathrm{I}^{14} \mathrm{C}\right]$ leucine $\left(10 \mathrm{mCi} \mathrm{mmol}{ }^{-1}, 0.2 \mu \mathrm{Ci} \mathrm{ml}^{-1}\right.$ ) into acid-precipitable material in 5MT-treated cultures: $5 \mathrm{MT}\left(100 \mu \mathrm{g} \mathrm{ml}^{-1}\right)$ was added at time 0 , DL-tryptophan $\left(20 \mu \mathrm{g} \mathrm{ml}^{-1}\right)$ at $60 \mathrm{~min}$. $\bigcirc$, Growing control culture; $\odot$, 5MT-treated culture; $\square$, 5MTtreated culture supplemented with tryptophan.

mRNA and stable RNA fractions the technique of coincident hybridization was employed (Midgley \& Gray, 197I; Midgley \& Smith, 1973). Experimental cultures were pulse-labelled with [ $\left.{ }^{32} \mathrm{P}\right]$ orthophosphate and the growing control cultures were pulse-labelled with $\left[5^{-3} \mathrm{H}\right]$ uracil as described by Smith \& Carr (1977). ${ }^{32} \mathrm{P}$-labelled RNA was cohybridized with ${ }^{3} \mathrm{H}$-labelled RNA at an overall DNA:RNA ratio of 5: I to minimize stable RNA hybrid formation (Smith \& Carr, 1977).

Estimations of RNA polymerization rates. The antibiotic rifampicin inhibits the initiation of new RNA chains while allowing completion of those already initiated. Using a technique devised by Pato $\&$ Von Meyenburg (1970), the time required to complete RNA synthesis after treatment with rifampicin was estimated. This value directly reflects the rate of polymerization of nascent RNA (Gray \& Midgley, 197I) but does not depend upon the rate of incorporation of labelled precursor. The assumption was made that the addition of rifampicin to a final concentration of $200 \mu \mathrm{g} \mathrm{ml}^{-1}$ does not significantly alter RNA polymerization rates.

\section{RESULTS}

In comparing the effects of deprivation of a required amino acid from an auxotrophic strain, Leu2or, and the addition of 5-methyltryptophan (5MT) to strain 625 of A. nidulans, we have sought to establish the major factor eliciting the phenomena described as being due to a reduced aminoacylation of tRNA. Thus the assumption that $5 \mathrm{MT}$ restricts growth by inhibiting tryptophan-specific aminoacyl-tRNA synthetases in $A$. nidulans is required. Figure I provides evidence to support this assumption. The incorporation of [G- $\left.{ }^{3} \mathrm{H}\right]-$ tryptophan into trichloroacetic acid (TCA)-precipitable material in $5 \mathrm{MT}$-treated cultures of strain 625 was inhibited compared with that in the growing control. The kinetics of incorporation were comparable to those of protein accumulation (Fig. $3 a$ ). The addition of DL-tryptophan (final concentration $20 \mu \mathrm{g} \mathrm{ml}^{-1}$ ) to $5 \mathrm{MT}$-treated cultures did not significantly affect the incorporation of $\left[\mathrm{I}^{14} \mathrm{C}\right]$ leucine into TCA-precipitable material (Fig. $\mathrm{I} b$ ).

Addition of $5 \mathrm{MT}$ to cultures of strain 625 or deprivation of leucine from cultures of strain Leu20I inhibited growth preventing both increases in cell size and cell division (Fig. 2). While leucine deprivation decreased the growth rate to 5 to $10 \%$ of that of the growing 

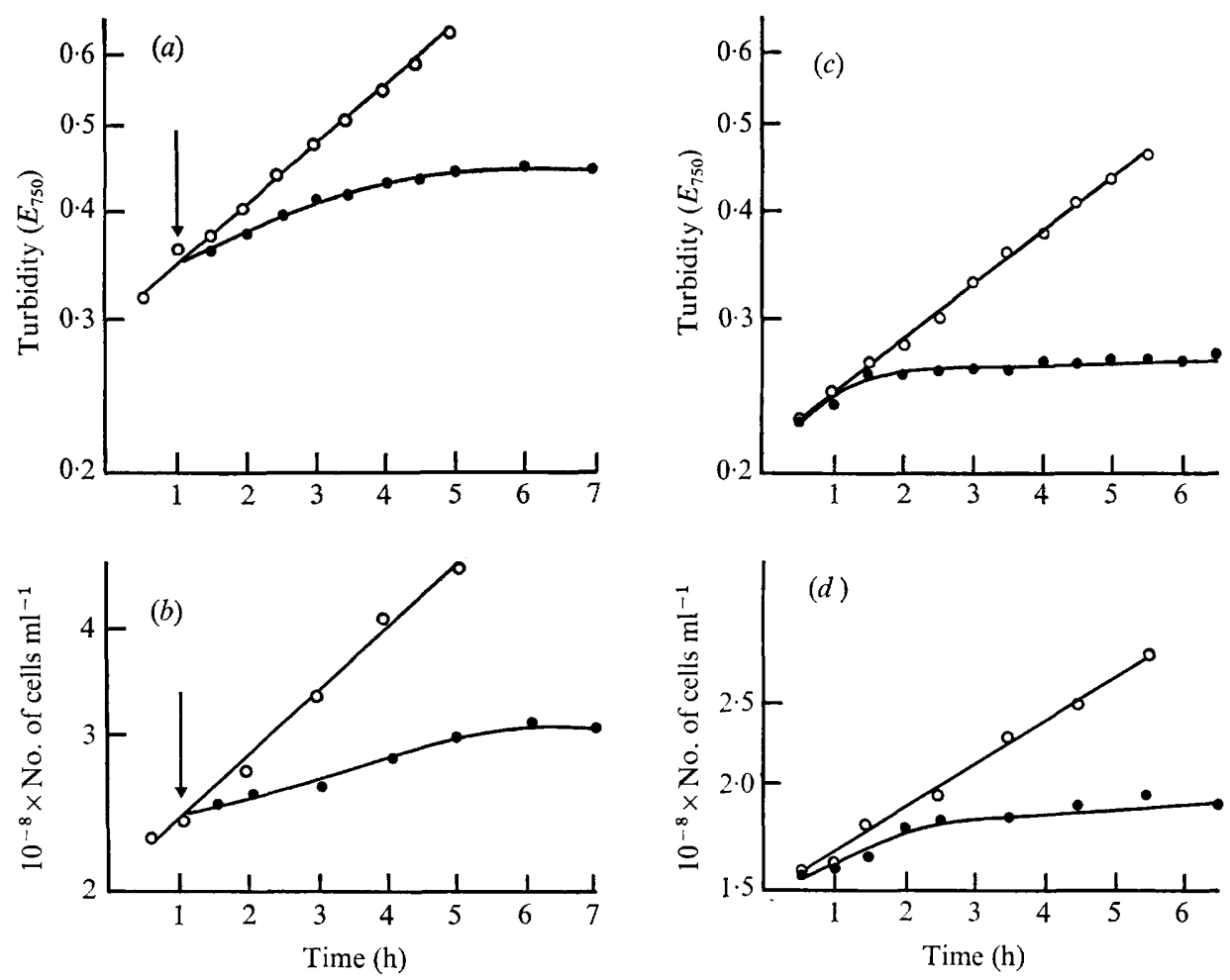

Fig. 2. Inhibition of growth of $A$. nidulans by $(a, b)$ addition of 5-methyltryptophan to cultures of strain 625 , or $(c, d)$ deprivation of leucine from cultures of strain Leu2or. The arrows (in $a, b)$ denote the addition of $5 \mathrm{MT}\left(100 \mu \mathrm{g} \mathrm{ml}^{-1}\right)$. $\bigcirc$, Growing control culture; $\Theta$, inhibited culture.

control, 5MT addition had a more gradual effect, about $4 \mathrm{~h}$ being required. Adding leucine to leucine-deprived cultures of strain Leu2or allowed a rapid return to exponential growth.

Both procedures inhibited the accumulation of RNA and protein, reducing the rates of accumulation to between Io and $15 \%$ of the growing control values. Again the inhibitory effect of $5 \mathrm{MT}$ (Fig. 3) was established more slowly than that of leucine deprivation. A similar pattern was shown in the accumulation kinetics of ppGpp. Both procedures induced the accumulation of $p p G p p$ and pppGpp within the culture but leucine deprivation repeatedly effected maximum concentrations of the nucleotides in half the time required by $5 \mathrm{MT}$ treatment (Fig. 4).

The relative flux of $\left.{ }^{[2} \mathrm{P}\right]$ orthophosphate into stable and messenger RNA fractions during leucine deprivation and $5 \mathrm{MT}$ treatment was determined by the technique of coincident hybridization. Thus the proportion of pulse-labelled readily hybridizable RNA (at a DNA:RNA ratio of $5: \mathrm{I}$ ) in inhibited cultures may be directly compared with that in a growing control for each estimate made. Assuming the relative rate of synthesis of mRNA in steadily growing cultures to be $40 \%$ (Smith \& Carr, 1977), the relative proportion in the inhibited samples may be expressed as a percentage providing corrections are made to account for the different specific radioactivities of the RNA samples. Figure 5 depicts the proportion of mRNA in pulse-labelled total cell RNA in leucine-deprived cultures. An increase from $40 \%$ to approximately $58 \%$ is noted. Similar though retarded effects were observed when $5 \mathrm{MT}$ was added to strain 625 cultures.

Providing a regulated degradation of nascent RNA is not involved, the regulation of RNA synthesis, which is a transcriptional event directed by a linear template, must depend on factors affecting either initiation, polymerization or termination of nascent RNA. A 


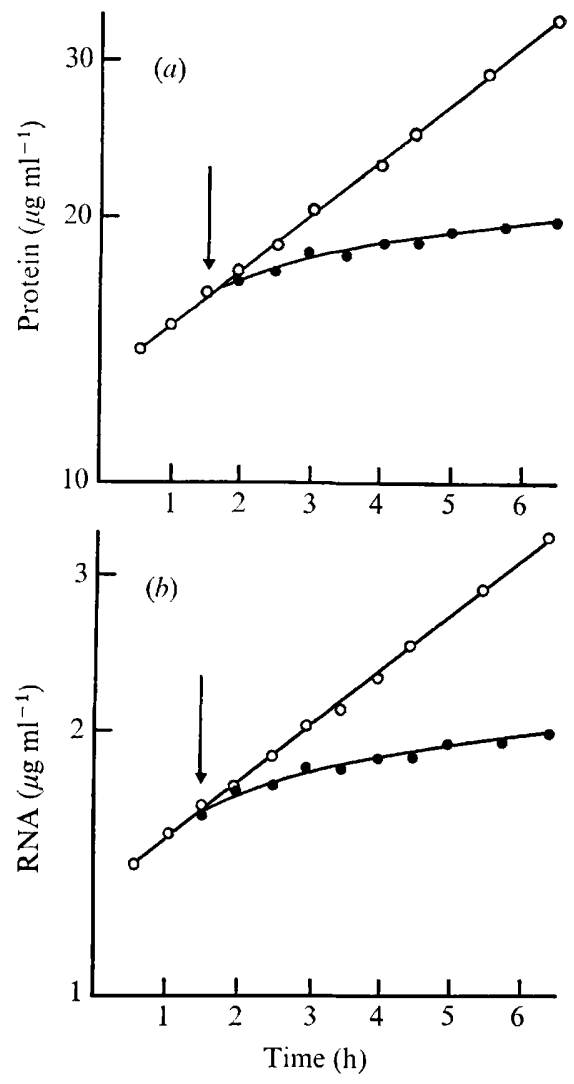

Fig. 3. Effect of 5-methyltryptophan on (a) protein accumulation and (b) RNA accumulation in $A$. nidulans. The arrows denote the addition of $5 \mathrm{MT}\left(100 \mu \mathrm{g} \mathrm{ml}^{-1}\right)$. $\bigcirc$, Growing control culture; , 5MT-inhibited culture.

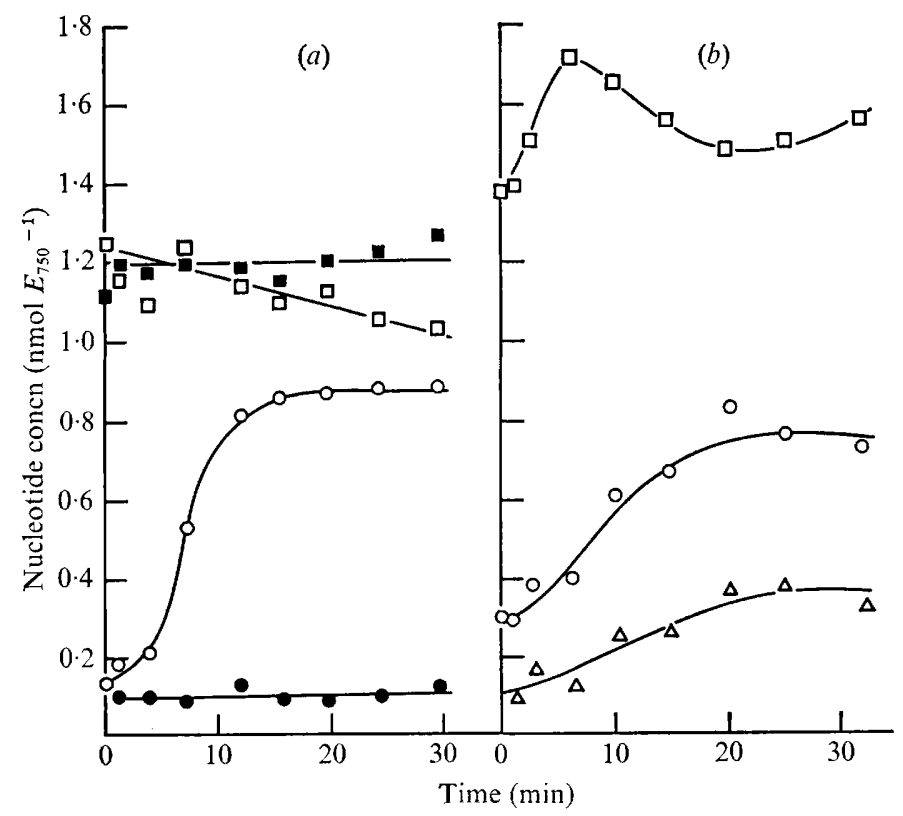

Fig. 4. Accumulation of guanosine nucleotides in (a) cultures of $A$. nidulans strain Leuzor deprived of leucine and $(b)$ cultures of $A$. nidulans strain 625 treated with 5 -methyltryptophan (100 $\mu \mathrm{g} \mathrm{ml}^{-1}$ ) at time $0 . \bigcirc$, ppGpp in inhibited cultures; $\odot$, ppGpp in growing control cultures; $\square$, GTP in inhibited cultures; $\boldsymbol{\square}$, GTP in growing control cultures; $\triangle$, pppGpp in inhibited cultures. 


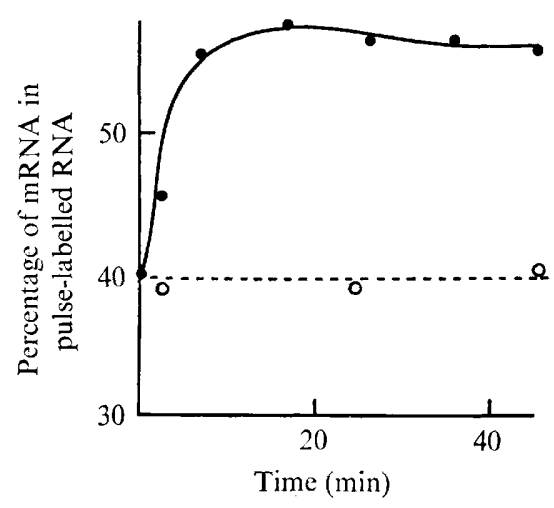

Fig. 5

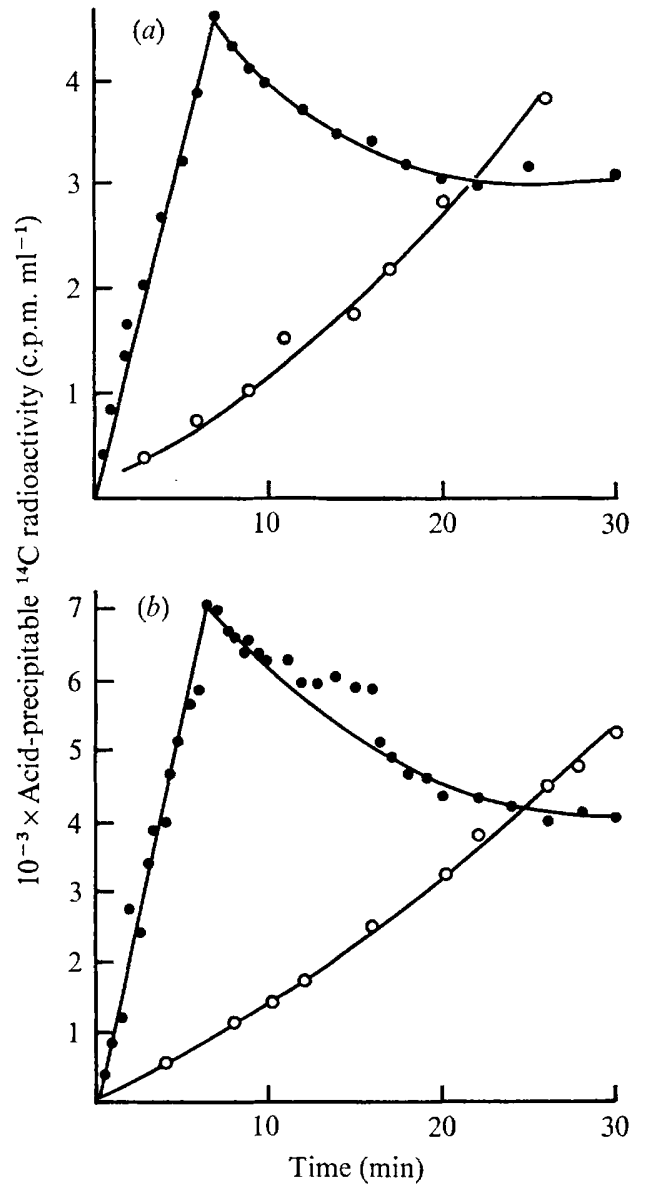

Fig. 6

Fig. 5. Proportion of mRNA in pulse-labelled RNA in leucine-deprived cultures of $A$. nidulans. Strain Leu2or was resuspended at time o. The first experimental sample was pulse-labelled immediately before commencing the centrifugation procedure. The results are expressed as a percentage of the total labelled RNA, assuming the value for the growing control (see text). $\bigcirc$, Growing control culture; $\odot$, leucine-deprived culture.

Fig. 6. Effect of leucine deprivation of $A$. nidulans strain LeuzoI on the time taken to complete RNA synthesis after treatment with rifampicin: (a) growing control culture; $(b)$ culture deprived of leucine for $30 \mathrm{~min}$. Rifampicin $\left(200 \mu \mathrm{g} \mathrm{ml}^{-1}\right)$ was added at time o simultaneously with [2- $\left.{ }^{14} \mathrm{C}\right]$ uracil (54 $\mathrm{mCi} \mathrm{mmol}^{-1}, 0 \cdot 2 \mu \mathrm{Ci} \mathrm{ml}^{-1}$ ). $\mathrm{O}$, Incorporation of ${ }^{14} \mathrm{C}$ radioactivity into DNA; $\bullet$, incorporation of ${ }^{14} \mathrm{C}$ radioactivity into $\mathrm{RNA}$.

non-coordinate synthesis of stable and messenger RNA fractions (such as that described above) may be found in purine deprivation of $E$. coli (Varney, Thomas \& Burton, 1970; Smith \& Midgley, 1973). The times required to complete RNA synthesis after addition of rifampicin to growing and leucine-deprived cultures of strain Leu2or are compared in Fig. 6. The results suggest that neither polymerization nor termination events play a significant role in the regulatory phenomenon.

\section{DISCUSSION}

Leucine deprivation and $5 \mathrm{MT}$ treatment of $A$. nidulans cultures curtail growth, RNA and protein accumulation, promote accumulation of high intracellular concentrations of ppGpp 
and pppGpp, and promote a non-coordinate synthesis of stable and messenger RNA. One may assess these results in two ways. The data support the concept of a mechanism regulating the extent and product of $A$. nidulans transcription, and suggest that the mechanism is elicited by reduced aminoacylation of tRNA rather than by reduction of amino-acid pools. The regulation appears to be directed at the initiation, rather than polymerization or termination, of nascent RNA chains. Secondly, the results may be compared with those from the extensive bacterial work (cf. Stent \& Brenner, 196I; Fiil \& Friesen, I968; Cashel \& Gallant, I969; Cashel, I969; Norris \& Koch, I972) which inspired this study. The similarity of the bacterial and blue-green algal phenomena imply that the suggested mechanism is akin to the bacterial RC function.

The accumulation of ppGpp during step-down procedures (Gallant, Margason \& Finch, 1972; Mann et al., 1975) has been attributed to reduced rates of turnover (Laffler \& Gallant, 1974), whereas the accumulation during amino-acid deprivation results from increased rates of synthesis. The synthesis of ppGpp has been shown to be dependent upon a ribosomeassociated protein known as 'stringent factor', the absence of which prevents ppGpp accumulation in $\mathrm{rel}^{-}$mutants (Haseltine et al., 1972). The accumulation of the guanosine nucleotides during leucine deprivation and 5-methyltryptophan inhibition of $A$. nidulans cultures indicates the ' $R C^{\text {str }}$ ' phenotype of this species and suggests the presence of a functional stringent factor.

The similarities between the bacterial and blue-green algal mechanisms are also observed during alleviation of the inhibitory effects and in the antagonistic effects of antibiotics. These will form the basis of a future communication.

\section{REFERENCES}

DE Boer, H. A., VAN Ooyen, A. J., AB, G. \& Gruber, M. (1973). The role of messenger RNA and peptidyl-tRNA in the synthesis of the guanine nucleotides MSI and MSII by ribosomes in vivo. FEBS Letters 30, 335-338.

Cashel, M. (1969). The control of ribonucleic acid synthesis in Escherichia coli. IV. Relevance of unusual phosphorylated compounds from amino acid starved stringent strains. Journal of Biological Chemistry 244, 3133-3I4I.

Cashel, M. \& Gallant, J. (I969). Two compounds implicated in the function of the RC gene in Escherichia coli. Nature, London 221, 838$84 \mathrm{I}$.

Cashel, M. \& Kalbacher, B. (1970). The control of RNA synthesis in Escherichia coli. V. Characterisation of a nucleoside associated with the stringent response. Journal of Biological Chemistry 245, 2309-23I8.

Eldin, G. \& Broda, P. (1968). Physiology and genetics of the ribonucleic acid control locus in Escherichia coli. Bacteriological Reviews 32, 206226.

Firl, N. R. \& Friesen, J. D. (I968). Isolation of relaxed mutants of E. coli. Journal of Bacteriology 95, 729-73I.

Gallant, J., Margason, G. \& Finch, B. (1972). On the turnover of ppGpp in E. coli. Journal of Biological Chemistry 247, 6055-6058.

Gray, W. J. H. \& Midgley, J. E. M. (I97I). The synthesis and stability of ribonucleic acid in rifampicin-inhibited cultures of Escherichia coli. Biochemical Journal 122, I 61-169.

Haseltine, W. A., Block, R., Gilbert, W. \&
Weber, K. (I972). MSI and MSII made on ribosome in idling step of protein synthesis. Nature, London 238, 381-384.

KAPLAN, S. (1969). Correlation between the rate of ribonucleic acid synthesis and the level of valyl transfer ribonucleic acid in mutants of $E$. coli. Journal of Bacteriology 98, 579-586.

KratZ, W. A. \& MYERS, J. (I955). Nutrition and growth of several blue-green algae. American Journal of Botany 42, 282-287.

LAFFler, T. \& Gallant, J. (1974). SpoT, a new genetic locus involved in the stringent response in $E$. coli. Cell $\mathbf{r}, 27-30$.

Lowry, O. H., Rosebrough, N. J., FARR, A. L. \& RANDALL, R. J. (I95I). Protein measurement with the Folin-phenol reagent. Journal of Biological Chemistry 193, 265-275.

MaAløe, O. \& KJeldgaARd, N. O. (I966). Control of Macromolecular Synthesis. New York: W. A. Benjamin.

MANN, N. \& CARR, N. G. (I973). A constant ratio of transfer to ribosomal ribonucleic acid in Anacystis nidulans grown with differing mean generation times. Biochemical Society Transactions $\mathbf{r}, 702-704$.

MANN, N. \& CARR, N. G. (I974). Control of macromolecular composition and cell division in the blue-green alga Anacystis nidulans. Journal of General Microbiology 83, 399-405.

ManN, N., Carr, N. G. \& Midgley, J. E. M. (1975). RNA synthesis and the accumulation of guanine nucleotides during growth shift-down in the bluegreen alga $A$. nidulans. Biochimica et biophysica acta 402, 4I-50. 
Midgley, J. E. M. \& Gray, W. J. H. (I97I). The control of ribonucleic acid synthesis in bacteria. The synthesis and stability of ribonucleic acid in chloramphenicol-inhibited cultures of $E$. coli. Biochemical Journal 122, I49-159.

Midgley, J. E. M. \& Smith, R. J. (1973). The control of ribonucleic acid synthesis in bacteria. Fluctuations in messenger RNA synthesis in cultures recovering from amino acid starvation. Biochemical Journal 138, I55-163.

Norris, T. E. \& KoCH, A.C. (1972). Effect of growth rate on the relative rates of synthesis of messenger, ribosomal and transfer RNA in Escherichia coli. Journal of Molecular Biology 64, 633-649.

Pardee, A. B., Shore, V. G. \& Prestidge, L. S. (1957). Incorporation of azatryptophan into proteins of bacteria and bacteriophage. Biochimica et biophysica acta 21, 406-407.

Pardee, A. B. \& Prestidge, L. S. (1958). Effects of azatryptophan on bacterial enzymes and bacteriophage. Biochimica et biophysica acta 27, 330-344.

Pato, M. L. \& Von Meyenburg, K. (1970). Residual RNA synthesis in Escherichia coli after inhibition of initiation of transcription by rifampicin. Cold Spring Harbor Symposia on Quantitative Biology 35, 497-504.
PigotT, G. H. \& Midgley, J. E. M. (1968). Characterization of rapidly labelled ribonucleic acid in Escherichia coli by DNA-RNA hybridization. Biochemical Journal II0, 25I-263.

SCHNEIDER, W. C. (1957). Determination of nucleic acids in tissues by pentose analysis. Methods in Enzymology 3, 680-684.

Smith, R. J. \& Carr, N. G. (1977). An investigation of RNA synthesis in Anacystis nidulans during exponential growth using techniques of RNADNA hybridization. Journal of General Microbio$\log y$ 98, 559-567.

Smith, R. J. \& Midgley, J. E. M. (1973). The effect of trimethoprim on macromolecular synthesis in Escherichia coli. General effects on ribonucleic acid and protein synthesis. Biochemical Journal 136, 225-234.

Stent, G. S. \& BRENNER, S. (196I). A genetic locus for the regulation of ribonucleic acid synthesis. Proceedings of the National Academy of Sciences of the United States of America 47, 2005-2014.

VARney, N. F., Thomas, G. A. \& Burton, K. (I970). Synthesis of ribonucleic acid in purine-deficient $E$. coli and comparison with the effects of amino acid starvation. Biochemical Journal 120, I28-132. 